\title{
THE ARGUMENT OF NATURE IN SHAKESPEARE'S “AS YOU LIKE IT”
}

\begin{abstract}
This paper examines the diverse ways in which the characters of Shakespeare's comedy "As you like it" praise or mock each other on behalf of nature. Shakespeare works during the Renaissance, when the ides of the ancient philosophers and rhetoricians are highly influential, and for this reason the argument of nature is presented with emphasis on Ancient Greek Philosophy and rhetoric. The notion of nature in the play is examined in three main aspects: (1) human nature (2) the objective reality opposing the human organic and inorganic world (3) constructive beginning, strength, God. The argument of nature in the play is examined in relation to upbringing, education and free will. Since "As you like it" is a pastoral comedy, the argument of nature is present in the very setting of the play, for this reason the last section of the study deals with the innate virtue of nature and its cleansing power over men.
\end{abstract}

Keywords: nature, Shakespeare, education, free will, fortune, ancient philosophy, rhetoric.

This paper is an abstract of a study on the argument of nature in Shakespeare's comedy "As you like", seen in the light of Ancient Greek philosophy. The study examines the argument of nature and its ties and relationships to upbringing, education and free will, through the diverse ways in which the characters of the play praise, abuse or make fun of one another on behalf of nature. Nature, being on one side the unchangeable field of predetermined human activity, and on the other an open ground for the expression of free will.

William Shakespeare (1564-1616) is hailed as England's national poet and greatest playwright of all time ${ }^{1}$. His plays, written in the end of the 16th and beginning of 17th century are crossing all national boundaries and are now staged more than ever - all over the world in different languages and different interpretations. The pastoral comedy "As you like it" is a meeting place for different human

${ }^{1}$ William Shakespeare (2015). In Encyclopædia Britannica. Retrieved from http://www.britannica.com/biog raphy/William-Shakespeare emotions and inclinations, for different social backgrounds, for different philosophical outlooks on the world. In this comedy Shakespeare's characters are often speaking with the words of wise philosophers - about the nature of things and the destiny of men.

The notion of nature comes from the latin

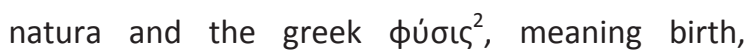
growth, creation and in that sense - the whole world as a process, as becoming. But on the other side, nature also means that which is unchangeable, a constant characteristic of things, ahaecceity. Human nature ${ }^{3}$ then is the aggregate of qualities that define a man or the channels through which he can express his free will. These qualities can vary significantly according to the philosophers - the man is a

\footnotetext{
${ }^{2}$ Novaya filosofskaya entsiklopediya (2000 - 2001) (New Encyclopedia of Philosophy (2000 - 2001)) in 4 vol. available at http://iph.ras.ru/elib/2440.html

${ }^{3}$ Filosofskii rechnik Cambridge (2009), (Cambridge philosophical Dictionary (2009)) p. 875
} 
bird without feathers, or the measure of all things, or a rational animal.

The notion of nature in the play is examined in three main aspects: (1) human nature (2) the objective reality, natural world, opposing human organic and inorganic world) (3) constructive beginning, strength, God.

The study begins with a review on the notion of nature as it was defined by the Ancient philosophers. The authors in this section are chosen by three main criteria: (1) that they have written on what nature is (2) that their ideas have been prominent during the Renaissance (3) that their ideas correlate to what is said about nature in the play. ${ }^{4}$

Shakespeare works during the Renaissance when the ancient's ideas of beauty, virtue, wisdom and justice are rediscovered and if a man is supposed to speak and write well then he must follow the examples of the playwrights and rhetoricians of antiquity. Rhetoric has been a mandatory discipline in the schools and eloquence has been a distinctive trait of the well-educated man of the time. This is obvious throughout the play in the words of the Duke's daughter Rosalind and the court jester Touchstone, who not only speaks of rhetoric, but wields it with mastery.

During the Renaissance rhetoric is the language of education and of the well-educated ${ }^{5}$. The ideas of the ancient philosophers find their way into the everyday language of the Elizabethan era through the Grammar schools, where the pupils are expected to memorize elaborate Latin phrases and participate in debates between one another. Through study and practice in the art of rhetoric, the students are expected to harness the power of language to heal and to do harm, and grow into el-

\footnotetext{
${ }^{4}$ The section includes the following: Thales, Heraclitus, Anaximander, Pythagoras, Empedocles, Democritus, Socrates, Plato, Aristotle, Cicero, Quintilian and Epictetus. This section is only briefly presented throughout the text of this abstract

${ }^{5}$ Aleksandrova, D. (2013). Osnovi na retorikata (Basics of rhetoric) Sofia, UI „Sv. Kliment Okhridski”, p.189
}

oquent and noble young men. The characters of the play love nothing more than a good conversation: Rosalind engages Orlando in a series of long debates, at the end of which they mutually convince each other that they want to get married, and the exiled duke seeks the company of Jaques because he loves to argue with him, especially when he is in one of his melancholic fits.

"As you like it" is a pastoral play, in the tradition of Hesiod and Theocritus, and in it Shakespeare writes about the golden age of the ancients, the migration of the souls and the music of the spheres, the wisdom and goodness of nature. About the shepherd Corin who is a "natural philosopher" and Rosalind who is filled with all graces wide enlarged. Empedocles said that the whole world is moved by the two opposing forces of love and enmity, so it is also in Shakespeare's play, where both sides of the human nature are present.

The argument of nature versus the argument of education

Examining the argument of nature in the play and its links to upbringing, education and free will, we will start with the words of the young Orlando, furious that what has been given to him by nature is scattered away by the lack of proper education. In his opinion, it is good education that distinguishes men from well fed cattle and the nobleman from the peasant. Also the lack of good manners is the result not only of the lack of education but of improper education.

Orlando, the third son of Sir Roland de Bois, is unhappy. Having not received what was left to him by his father, he is forced to lead a life that is not corresponding to his desires. The basic discrepancy between what nature has given him and the unfortunate turn of events, the inability to develop and fully express his natural potentialities, have created a strong conflict in the young man. Even though he is well fed and gains on weight, the lack of proper education and realization is still troubling him. 
Staged in the very beginning of the play, the question of education is in direct opposition to the question of diet. It is true that the ox in the barn and the animals on the dunghills can find a good meal and gain on weight, but something more is needed for a full and happy life. This goes not only for people, but also for the livestock - Orlando makes a reference to the horses that also need training to achieve their high results.

When presenting his case Orlando uses the following phrases: "for my part, he keepes me rustically at home, or (to speak more properly) staies me heere at home vnkept: for call you that keeping for a gentleman of my birth, that differs not from the stalling of an Oxe?", "besides this nothing that he so plentifully giues me, the something that nature gaue mee, his countenance seemes to take from me", "...and as much as in him lies, mines my gentility with my education", "I am helping you to mar that which God made, a poore vnworthy brother of yours with idlenesse"

In these excerpts from the beginning of the play the notion of nature is present in the following words and phrases: "gentleman of my birth"; "gentility"; "something that nature gave me"; "that which God made". We see the ease with which Shakespeare uses together the words "birth", "nature" and "God". This interchangeability continues throughout the play - not as an example of a terminological chaos, but as a representation of the way those words were used together during the Renaissance, when the church was losing its ground and people were turning toward the ideas of the ancients. Seneca, who has been very popular as a playwright and a philosopher during that time, in his work on natural philosophy Naturales quaestiones $(\mathrm{II}, 45)^{6}$, says that every name is appropriate to the supreme guardian and ruler of the universe. We can call him fate because all things depend on him, we can call him providence because

\footnotetext{
${ }^{6}$ Antichna filosofiya, antologiya (1994) (Ancient philosophy. Anthology), Sofia, St. Zagora, “Ideya”, pp. 508-509
}

all events in the world's drama are moved by his wise counsel alone, or we can call him nature because from him all things derive their being. If you prefer to call him the world, you will not be in error, because he is everything that you can see, he has all his parts in him and is himself the source of his inherent power.

The second place where the question of nature and education is discussed is in Act three, second scene, in the words of the shepherd Corin, who from the position of his native wisdom also outlines the difference between natural potentialities, received in inheritance, and the mind that has been cultivated through education.

The clown Touchstone and the shepherd Corin give us their understanding of philosophy in a genuine conversation upon life in the forest:

Corin: And how like you this shepherds life Mr Touchstone?

Clowne: Truely Shepheard, in respect of it selfe, it is a good life; but in respect that it is a shepheards life, it is naught. In respect that it is solitary, I like it verie well: but in respect that it is priuate, it is a very vild life. Now in respect it is in the fields, it pleaseth mee well: but in respect it is not in the Court, it is tedious. As it is a spare life (looke you) it fits my humor well: but as there is no more plentie in it, it goes much against my stomacke. Has't any Philosophie in thee shepheard?

Corin: No more, but that I know the more one sickens, the worse at ease he is: and that hee that wants money, meanes, and content, is without three good frends. That the propertie of raine is to wet, and fire to burne: That good pasture makes fat sheepe: and that a great cause of the night, is lacke of the Sunne: That hee that hath learned no wit by Nature, nor Art, may complaine of good breeding, or comes of a very dull kindred

Clowne: Such a one is a naturall Philosopher...

This dialogue gives us a brief outlook on the ideas of the first natural philosophers, who put a special emphasis on the movement of the celestial bodies. The very first of them, Thales, was able to 
predict solar eclipses, because he was aware that they are caused by the passing of the Moon in front of the Sun. The words of Corin also sound like the sentences of another famous natural philosopher, Heraclitus, who said that if there was no Sun, we would live in a perpetual night ${ }^{7}$; it is sickness that makes health pleasant and good, hunger - satiety, and weariness - rest $^{8}$. The clown Touchstone also speaks with the words of Heraclitus, when he shares his impressions about life among nature: "As it is a spare life (looked you) it fits my humor well: but as there is no more plentie in it, it goes much against my stomacke". Corin's observations on the characteristics of rain and fire are similar to Anaximander's conclusions on the oppositions of the different elements of nature: air is cold, water - moist, fire - hot, if one of them was infinite, the others would have ceased to be. ${ }^{9}$

Again in brief formulations Corin expresses his opinion on the origins of the human mind in particular and the human nature as a whole: the intellect is congenial to a certain extent, but it can also be further developed through proper upbringing and education, through Art. "That hee that hath learned no wit by Nature, nor Art, may complaine of good breeding, or comes of a very dull kindred."

In Act Three, third scene the clown Touchstone whines that nature hasn't been generous enough towards his beloved Audrey. The gods haven't made her poetical and she is unable to understand his contentious jokes. This is a misuse of the argument of nature - it is obvious from the dialogues throughout the play that the clown has received a splendid education and Audrey hasn't been schooled at all. And still she has common sense and a natural inclination towards honesty and justice that can't be overturned by all his sophisms. She

\footnotetext{
${ }^{7}$ Antichna filosofiya, antologiya (1994) (Ancient philosophy. Anthology), Sofia, St. Zagora, “Ideya”, p. 112.

8 Ibid, Stobaeus, Anthology, I, 177, p.113.

9 Antichna filosofiya, antologiya (1994) (Ancient philosophy. Anthology), Sofia, St. Zagora, "Ideya", pp. 96-97
}

doesn't understand the words he is speaking but she has a good nature.

And so when Touchstone, embittered by the lack of good wit and understanding in his beloved, tries to blame the gods for not giving her a predisposition towards poetry, it is obvious that the question is not so much about her natural potentialities but about the lack of proper education. The clown has probably mastered the trivium (grammar, rhetoric and logic) and the quadrivim (arithmetic, geometry, music and astrology) since this was the good education of the time. And as is obvious from all the dialogues, he not only speaks of rhetoric, but wields it with mastery - he even tries to pass on some of his knowledge in rhetoric to the country man William. The amusing disagreements and misunderstandings in the dialogue come over the incongruity between the education of the clown, who uses both the complicated scholastic terms and the simple popular slang, and Audrey's ignorance in terms of this kind of knowledge. This is also obvious in the dialogue between the clown and William, who also hasn't received a classical education and is oblivious to his elaborate phrases. So it is necessary for Touchstone to translate his intentions towards their common interest Audrey in more popular terms:

Clowne: Giue me your hand: Art thou Learned? William: No sir

Clown: Then learn this of me, to have, is to have. For it is a figure in Rhetoric, that drink being powered out of a cup into a glass, by filling the one, doth empty the other. For all your Writers do consent, that ipse is he: now you are not ipse, for I am he William: Which he sir?

Clowne: He sir, that must marry this woman: Therefore you Clowne, abandon: which is in the vulgar, leave the society: which in the boorish, is company, of this female: which in the common, is woman: which together, is, abandon the society of this Female, or Clowne thou perishes: or to thy better vnderstanding, dyest; or (to wit) I kill thee, make thee away, translate thy life into death, thy liberty 
into bondage: I will deal in poison with thee, or in bastinado, or in stele: I will bandy with thee in faction, I will ore-run thee with police: I will kill thee a hundred and fifty ways, therefore tremble and depart.

Eventually the clown achieves victory through the power of language alone - even though his words are abusive and threatening, the disagreement ends peacefully in his favor.

By the examples so forth presented we see how in the course of the play the proposed idea is that nature, natural gifts, are not the only factor in the development of reason - men also need good environment, good upbringing and education. The argument of nature is valid only when it takes into account the argument of education.

The argument of nature versus the argument of fortune. Free will and responsibility. Beauty and virtue.

When we discuss the role of natural gifts, upbringing and education, even in the very beginning of the play we can also see the complex connections and relationships between nature, fortune, predetermined circumstances and the expression of free will. Orlando knows his true nature and has a purpose. The spirit of his father, which still lives within him, starts to mutiny against the poor conditions in which he is placed by his brother - the lack of education and opportunity. Orlando takes responsibility for his life and departs from his brother's ward, seeking his own fortune.

In Act one, second scene the two young girls, Celia and Rosalind, are talking about Fortune and the unjust ways in which her gifts are bestowed. Rosalind argues that while Nature determines the character and ability of men, it is Fortune that takes care of everything else from then on - by sending us good or bad luck, by placing us in one situation or another.

Whenever we use the argument of nature, we should always keep in mind that sometimes chance and spontaneity do exist in the world and even nature's fairest creation may by fortune fall into the fire. But also throughout the play in the actions of Rosalind and Orlando we see that men are not bound by fate, and by taking responsibility and expressing their free will they could build their own fortune.

Rosalind, the daughter of the exiled Duke, is beautiful and wise. The courtier Le Beau says that the people praise her for her virtues. She says that since the age of three she has been apprenticed to a great magician, most profound in his art. Taking into account her conversation skills, delicate sense of humor and verse, it is most probable that this great art was rhetoric. In all the dialogues of the play we can see her serious reflections on the situation and the other characters. For she knows that time runs differently for different people and compares the orators to the lovers ${ }^{10}$, who when having nothing to say, go for a kiss or start coughing. Also in the dialogue with the shepherdess Phoebe, Rosalind is aware with the power of language to heal or to do harm. ${ }^{11}$

So being wise and virtuous Rosalind takes active actions towards achieving her happiness - with passion and reason. It's true that she's in love with Orlando, but she does not rush blindly into his arms relying on fortune alone, instead she decides to test him first and see if they really are meant for each other. She challenges Orlando to a contest and through a series of conversations they mutually convince each other that they want to get married.

In act three, third scene the clown Touchstone tries to seduce the shepherdess Audrey with his elaborate phrases and sophisms. Although she is not familiar with the meaning of the words "poetical" and "features" Audrey has common sense about what is good in life and she wants to be true and honest herself. She says: "I do not know what Poetical is: is it honest in deed and word: is it a true

\footnotetext{
${ }^{10}$ Act four, Scene one.

${ }^{11}$ Act three, Scene five.
} 
thing?" And despite of Touchstone's misleading comments, tying together honesty and ugliness, Audrey makes her choice and stays firm, and in that way she determines what happens further in the play - Audrey and Touchstone join together in lawful marriage. And even though she hasn't been schooled, like Celia and Rosalind, she has a natural inclination towards good and so in her case, as it is with the other two girls, Fortune is on the side of reason and virtue.

Democritus says that people have created the image of Chance as an excuse for their own stupidi$\mathrm{ty}^{12}$. Fortune rules over the lives of men only when they indulge in idleness and fail to moderate their desires.

\section{Nature and justice}

All the quarrels in the end are being resolved, when the two villains of the play, Duke Frederick and Orlando's eldest brother Oliver, find themselves in the forest. Even though they go there with evil intentions, they both return to their better selves among the trees.

"As you like it" is a pastoral comedy and in it Shakespeare writes about the beauty, virtue and justice of nature, but also about the difficulties of life away from the comforts of the court. Charles the wrestlers says ${ }^{13}$ that the old duke and his cheerful men live carelessly within the Forest of Arden, like people did in the golden age. But the truth is that life outside the castle is difficult and demanding $^{14}$, the exiled duke and his men have to prey up-

\footnotetext{
${ }^{12}$ Antichna filosofiya, antologiya (1994). (Ancient philosophy. Anthology), Sofia, St. Zagora, “Ideya”, pp. 186187.

${ }^{13}$ Act one, scene one, "Charles: They say he is already in the Forrest of Arden, and a many merry men with him; and there they live like the old Robin Hood of England: they say many young Gentlemen flock to him every day, and fleet the time carelessly as they did in the golden world."

${ }^{14}$ Act two, scene one
}

on the noble beasts of the forest for their sustenance and bear the changing of the seasons, the rain and the icy fangs of the scolding wind. And still, in spite of all these inconveniences, this exile among nature allows them to get closer to the true meaning of life, hidden in the language of the trees and the sermons of the stones. The Duke Senior refers to his followers as "brothers in exile", since life in court has turned his own real brother into his worst enemy, life in nature - where all man are equal in front of their creator - has given him the true companionship and love that had been sadly missing in the artificial manners of the palace.

The artificial and pretentious manners of the courtiers are also an object of ridicule for the clown Touchstone in his dialogue with the shepherd Corin. ${ }^{15}$ And whether or not Corin is indeed a natural philosopher, he finds peace and satisfaction in his life, which the clown is unable to disturb with all his tricks and misleading questions. Corin leads a simple and honest life in the forest, he earns what he eats, he hates no man and envies no man's happiness. And although the clown tries to dissuade him and make him feel ashamed of his earnest living, their disputation ends in a tie, interrupted by the arrival of Rosalind.

The simple and honest life in the forest is a remedy for men's vile passions and desires. Through what happens in the lives of the villains in the play, through their personal stories, Shakespeare outlines the idea of the innate justice of nature and its cleansing power over men. Duke Frederick repents from his evil when he meets an old hermit living in the forest. Oliver, who is ready to kill Orlando, is himself threatened with violent death and is saved by the very brother he wanted to kill. Life close to nature urges men to better

\footnotetext{
${ }^{15}$ Act three, scene two, Touchstone is mocking the habit of the courtiers to perfume their hands with civet musk: "Clown: ...learn of the wise and perpend: Ciuet is of a baser birth then Terre, the very uncleanly flux of a Cat..."
} 
know themselves and turns them towards their inherent virtues.

So in this case we are claiming that something is good, virtuous and beautiful because it is natural or because it is close to nature. But this use of the argument of nature is valid only if we believe that men and the world are inherently noble and just. If, on the other hand, we are inclined towards a more pessimistic view of things, like the melancholic Jaques, then men can only bring their bloodlust and savagery to nature, which in turn punishes them with bad weather and all sorts of perils. And while it is true that life close to nature urges men to better know themselves, it is also true that Socrates was not found of long excursions in the country (Phaedrus, $230 d)^{16}$ - he preferred to tackle vice and virtue on the streets of Athens, among his fellow man, not in the solitude of some desolate forest.

\section{Conclusion}

By showing us the actions of the different characters, coming from different social backgrounds, Shakespeare guides us towards the idea that human nature is inherently good and can get even better through proper upbringing and education. The shepherdess Audrey, even though she hasn't been schooled, still has in her a natural inclination towards honesty. And in her case, as it is with Celia and Rosalind, Fortune is on the side of reason and virtue.

Used separately, relying on natural potentialities, but ignoring such factors as upbringing, education and free will, there is a risk that the argument of nature may refer to men and their role in society as something completely predetermined. But the argument of nature can also support and encourage men to realize their full potential. Since it is founded in the believe that nature is inherently good, when we use the argument of nature we should also take responsibility, exercise our free will, and take action toward achieving that good, through proper education and through creating a good living environment.

\section{REFERENCES}

Aleksandrova, D. (2013). Osnovi na retorikata (Basics of rhetoric) Sofia, UI „Sv. Kliment Okhridski"

Antichna filosofiya, antologiya (1994) (Ancient philosophy. Anthology), Sofia, St. Zagora, "Ideya"

Novaya filosofskaya entsiklopediya (2000 - 2001)

(New Encyclopedia of Philosophy (2000 2001)) in four vol. available at: http://iph.ras.ru/enc.htm.

Platon. Dialozi. (1982), (Plato, dialogs (1982)) Vol. Sofia, „Nauka i izkustvo

Filosofskii rechnik Cambridge (2009), (Cambridge philosophical Dictionary (2009))

Shekspir, W. Izbrani komedii. (1983), Sofia, Narodna kultura

Encyclopedia Britannica Online: available at: http://www.britannica.com/.

Shakespeare, W., Mr. William Shakespeare's comedies, histories, and tragedies: faithfully reproduced in facsimile from the edition of 1623, London, Methuen \& Co., pp. 185207, Available at:

http://en.wikisource.org/wiki/As You Li ke It.

16 Platon. Dialozi. (1982), (Plato, dialogs (1982)) Vol. So-

fia, „Nauka i izkustvo" (you don't leave the city) 